\title{
Study on Phosphorus Characteristics in Sediments of Xiangxi Bay, China Three-Gorge Reservoir
}

\author{
Huajun Luo', Defu Liu², Yingping Huang ${ }^{3}$ \\ ${ }^{1}$ College of Biological and Pharmaceutical Science, China Three Gorges University, Yichang, China \\ ${ }^{2}$ College of Hydroelectric \& Environment, China Three Gorges University, Yichang, China \\ ${ }^{3}$ Engineering Research Center of Eco-Environment in Three Gorges Reservoir Region, Ministry of Education, \\ China Three Gorges University, Yichang, China \\ Email: luohuajun@21cn.com
}

Received 14 March 2015; accepted 30 March 2015; published 31 March 2015

Copyright (C) 2015 by authors and Scientific Research Publishing Inc.

This work is licensed under the Creative Commons Attribution International License (CC BY).

http://creativecommons.org/licenses/by/4.0/

(c) $\underset{\mathrm{EY}}{\mathrm{BY}}$ Open Access

\begin{abstract}
To explore the environment influence of the sediments in Xiangxi Bay (China Three-Gorge Reservoir), spatial and temporal distribution characteristics of total phosphorus (TP), phosphorus fractions, dissolved total phosphorus (DTP) of pore water and overlying water in the sediments were investigated. In surveys, the sampling was undertaken from six sites of Xiangxi Bay on 29 March 2009 and 28 March 2010 . TP contents ranged from $1111.29 \mathrm{mg} / \mathrm{kg}$ to $1941.29 \mathrm{mg} / \mathrm{kg}$ with the mean value of $1533.09 \mathrm{mg} / \mathrm{kg}$ in 2009 spring and $1600.48 \mathrm{mg} / \mathrm{kg}$ in 2010 spring. Five fractions of sedimentary phosphorus, including loosely sorbed phosphorus $\left(\mathrm{NH}_{4} \mathrm{Cl}-\mathrm{P}\right)$, redox-sensitive phosphorus (BD-P), metal oxide bound phosphorus ( $\mathrm{NaOH}-\mathrm{P}$ ), calcium bound phosphorus (HCl-P), and residual phosphorus (Res-P), were separately quantified. DTP of pore water and overlying water all have positive correlations with $\mathrm{NH}_{4} \mathrm{Cl}-\mathrm{P}$ and $\mathrm{BD}-\mathrm{P}$, which indicated that $\mathrm{NH}_{4} \mathrm{Cl}-\mathrm{P}$ and $\mathrm{BD}-\mathrm{P}$ were the main fractions that can easily release phosphorus in the sediments of Xiangxi Bay.
\end{abstract}

\section{Keywords}

Phosphorus, Characteristics, Fractions, Sediments, Xiangxi Bay

\section{Introduction}

Reservoir eutrophication has become a serious environmental problem in China. Biological productivity in reservoir is strongly related to the concentration of phosphorus (P). It has been shown that the sediment can act as 
an internal source of phosphorus for the overlying water [1]-[3]. P can be transferred from water to sediment through biochemical and physical reactions such as ion exchange, adsorption, and precipitation [4], and also could be released from sediments as the overlying water quality changing [5]-[8].

China Three-Gorge Dam (2335 m long and $185 \mathrm{~m}$ high) is the world's largest dam, and the reservoir created by it has an area of $1080 \mathrm{~km}^{2}$ in 2009 [9]. The Xiangxi River, which lies $38 \mathrm{~km}$ upstream from the Dam, is 94 $\mathrm{km}$ long with a watershed of $3099 \mathrm{~km}^{2}$ (between $110^{\circ} 25^{\prime} \mathrm{E}$ and $111^{\circ} 06^{\prime} \mathrm{E}$ long., $30^{\circ} 57^{\prime} \mathrm{N}$ and $31^{\circ} 34^{\prime} \mathrm{N}$ lat.) [10]. With impoundment of Three-Gorge Reservoir (TGR), the water flow velocity in Xiangxi Bay dropped from the original $0.43-0.92 \mathrm{~m} / \mathrm{s}$ [11] to $0.0020-0.0041 \mathrm{~m} / \mathrm{s}$ [12]. As water temperature increased in spring, there were algal blooms with prolonged retention time and rich nutrients in Xiangxi Bay.

In Xiangxi Bay, the distributions and influences of phosphorus in water body have been studied [13]-[16]. However, the spatial and temporal variability of phosphorus and phosphorus bioavailability in sediments of Xiangxi Bay still need to be fully studied. So the objective of this study was to investigate total phosphorus and phosphorus fractions characteristics in the sediments of Xiangxi Bay. The phosphorus relationships among sediment, pore water and overlying water were also studied.

\section{Materials and Methods}

\subsection{Sampling and Sample Preparation}

The sampling was undertaken from six sites of Xiangxi Bay (Figure 1) on 29 March 2009 and 28 March 2010.

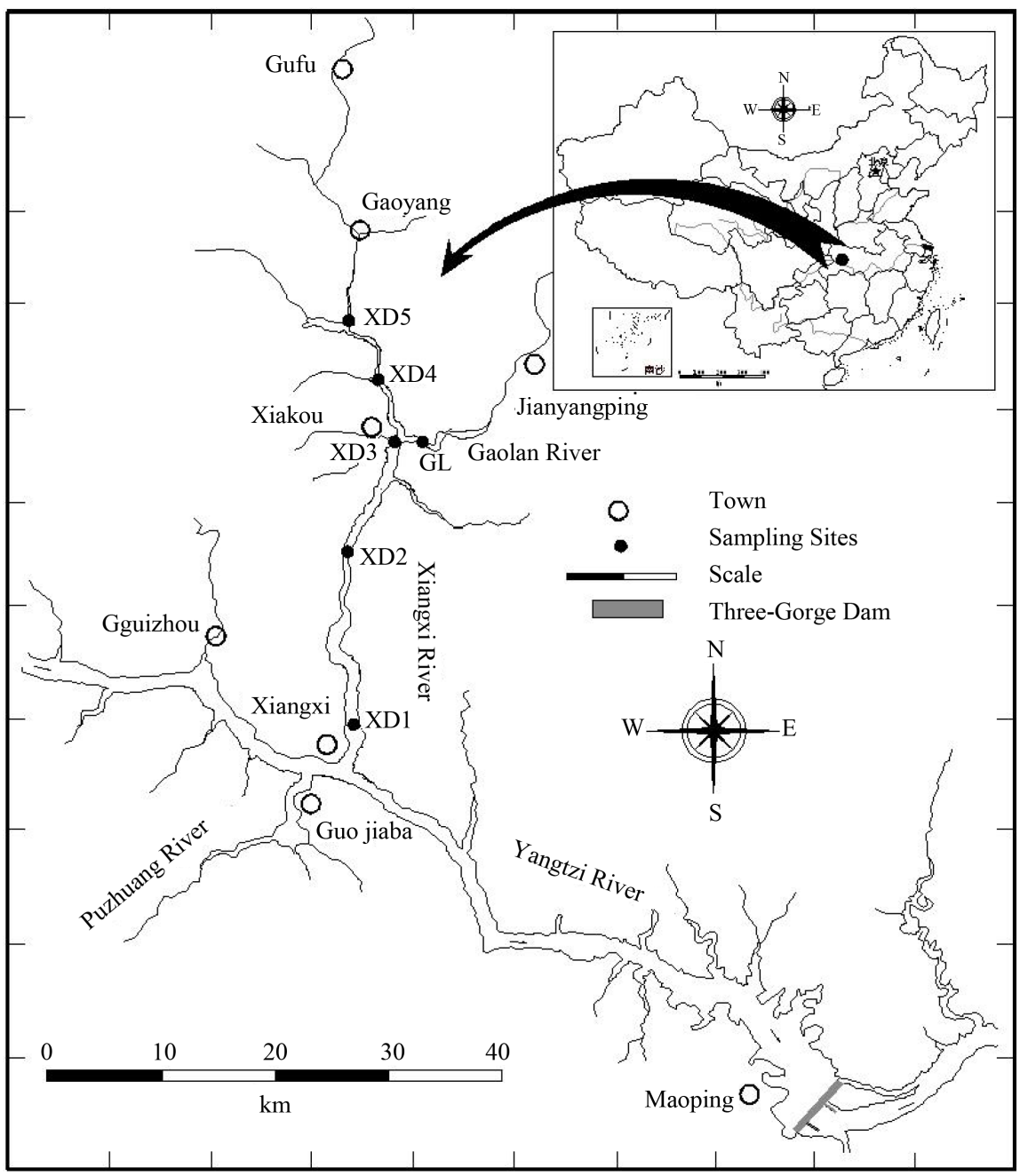

Figure 1. Sediment sampling sites in Xiangxi Bay. 
Sites (XD1-XD5) are on the Xiangxi River. Site GL is located at the downstream of Gaolan River, which is the largest tributary of the Xiangxi River. Sediments with a 15 -cm overlying water column were collected using acid-washed PVC core tubes (diameter $65 \mathrm{~mm}$ ). The overlying water was siphoned off, filtered and stored at $4^{\circ} \mathrm{C}$ for analysis. The top $5 \mathrm{~cm}$ of sediment cores were segmented and stored in air-sealed plastic bags at $4^{\circ} \mathrm{C}$. Pore water was separated from the sediments by centrifugation (3000 rpm, $10 \mathrm{~min}$ ) followed by filtration of the supernatant (passing a Whatman $0.45 \mu \mathrm{m}$ pore-size filter). Prior to analysis the sediment samples were freezedried and ground to pass through a 100-mesh sieve.

\subsection{Sediment Analysis}

\subsubsection{Total Phosphorus (TP)}

Freeze-dried sediment (0.7000 g) was put into a $50-\mathrm{ml}$ glass tube, and digested with potassium persulphate and $30 \% \mathrm{v} / \mathrm{v}$ sulphuric acid. After digestion, the solution was cooled, centrifuged and filtered by Whatman $0.45 \mu \mathrm{m}$ pore-size filter. Then phosphorus was determined using the ammonium molybdate-ascorbic acid (AMAA) method [17]. A blank was processed simultaneously.

\subsubsection{Phosphorus Fractions}

The contents of different phosphorus fractions were determined using the sequential extraction scheme suggested by Psenner et al. [18] with the modifications of Hupfter et al. [19] (Figure 2), which based on differences in reactivity of solid phases to different extractant solutions. The extraction procedure divided inorganic phosphorus (IP) fractions into loosely sorbed $\mathrm{P}\left(\mathrm{NH}_{4} \mathrm{Cl}-\mathrm{P}\right)$, redox-sensitive $\mathrm{P}$ (BD-P), metal oxide bound $\mathrm{P}$ (NaOH-P) and calcium bound $\mathrm{P}$ (HCl-P). The difference between TP and IP is the residual P (Res-P) fraction, which contains organic $\mathrm{P}$ and refractory $\mathrm{P}$ compounds.

\subsection{Water Samples}

Dissolved total phosphorus (DTP) of pore water and overlying water were determined in the laboratory using AMAA method.

All samples were analyzed in triplicates and the data were expressed as the average.

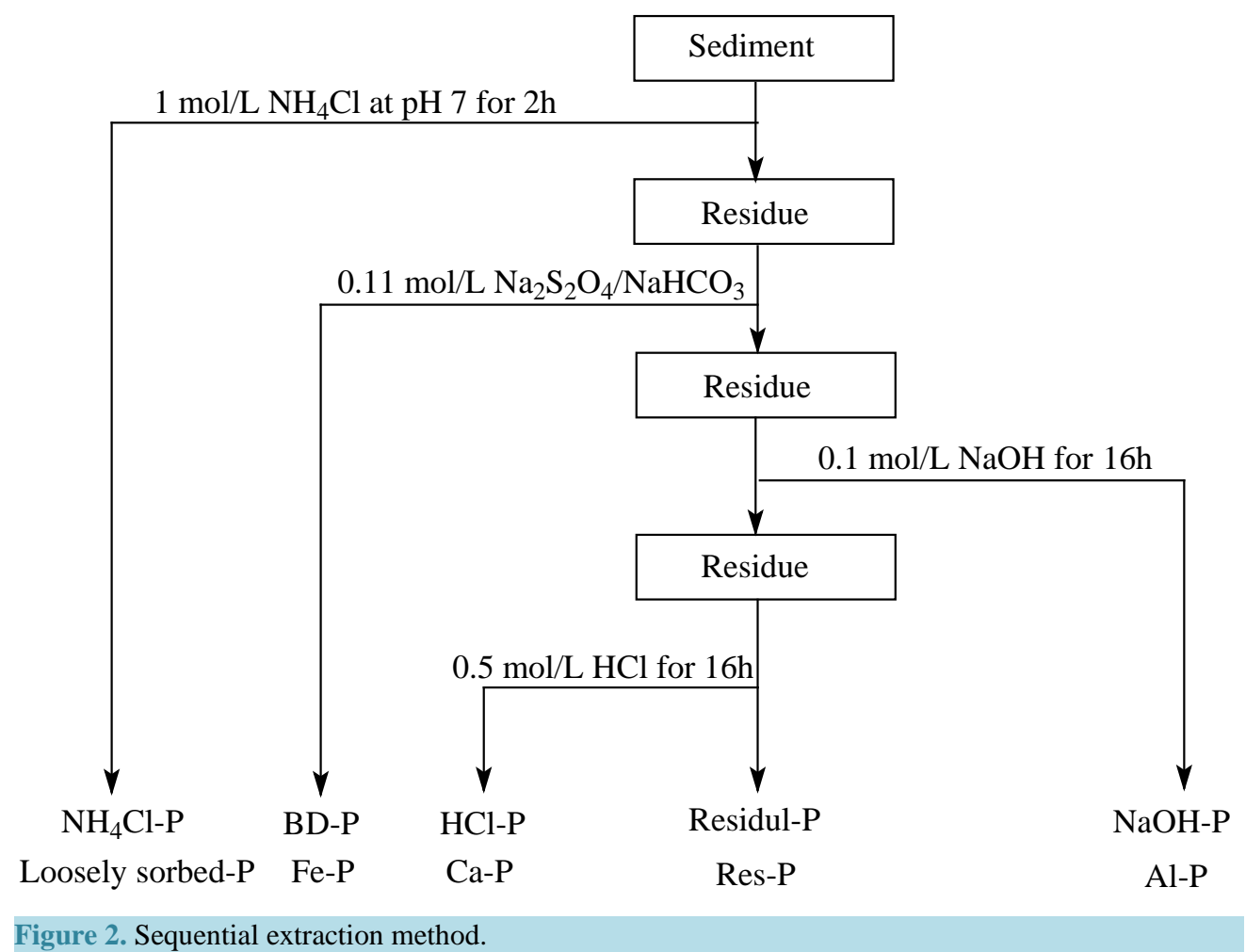




\section{Results and Discussion}

\subsection{Sediment TP Characteristics}

Because Xiangxi river basin is in high phosphorus background region, TP contents in sediments of Xiangxi Bay were high, which maximum value reached $1941.29 \mathrm{mg} / \mathrm{kg}$ (XD1, March 2010). Mean values of TP contents in sediments were $1533.09 \mathrm{mg} / \mathrm{kg}$ (March 2009) and $1600.48 \mathrm{mg} / \mathrm{kg}$ (March 2010), respectively. As the water flow velocity from upper to down reaches of Xiangxi Bay decreased, sedimentation of phosphorus increased as moving to the estuary. TP contents in sediments decreased from down to upper reaches of Xiangxi Bay except TP content of site XD4 in 2010 (Figure 3). In site XD4 (March 2010), TP contents increased 31.32\% than that in 2009 spring and reached to $1886.65 \mathrm{mg} / \mathrm{kg}$. TP contents of tributary site GL in sediments were $1359.65 \mathrm{mg} / \mathrm{kg}$ (March 2009) and $1484.88 \mathrm{mg} / \mathrm{kg}$ (March 2010), which all near the mean values of TP in Xiangxi Bay.

\subsection{Sediment Phosphorus Fractions}

For mean values of all the sediment samples phosphorus fractions were in the order: Res-P $>$ HCl-P $>$ NaOH-P $>$ $\mathrm{NH}_{4} \mathrm{Cl}-\mathrm{P}>\mathrm{BD}-\mathrm{P}$. But there were different sequences in different sites (Figure 4): XD1 (March 2009) with sequence of Res-P > HCl-P > NaOH-P > BD-P > NH 4 Cl-P; XD3 (March 2010) with sequence of HCl-P > NaOH-P $>$ Res-P > NH ${ }_{4}$ Cl-P $>$ BD-P; XD5 (March 2009 and March 2010) with sequence of HCl-P $>$ Res-P $>$ NaOH-P > NH $\mathrm{NH}_{4} \mathrm{Cl}-\mathrm{P}>$ BD-P; GL (March 2009 and March 2010) with sequence of NaOH-P > HCl-P > Res-P > $\mathrm{NH}_{4} \mathrm{Cl}-\mathrm{P}>\mathrm{BD}-\mathrm{P}$. It was reported that in heavily polluted lakes, the rank order of NaOH-P $>\mathrm{HCl}-\mathrm{P}$ was found [1], while the oppositive order of HCl-P > NaOH-P was in mesotrophic lakes [20]. So the rank order of phosphorus fractions suggests that the sediments of Xiangxi Bay are mostly mesotrophic, except for site GL.

$\mathrm{NH}_{4} \mathrm{Cl}-\mathrm{P}$ represents the loosely sorbed $\mathrm{P}$ in the sediments [20] [21]. In Xiangxi Bay, mean values of $\mathrm{NH}_{4} \mathrm{Cl}-\mathrm{P}$ contents in sediments were $95.06 \mathrm{mg} / \mathrm{kg}$ (March 2009) and $131.01 \mathrm{mg} / \mathrm{kg}$ (March 2010), respectively. $\mathrm{NH}_{4} \mathrm{Cl}-\mathrm{P}$ contents of all sampling sites in 2010 were higher than that in 2009 except XD2 (Figure 4(a)). In 2010, the highest $\mathrm{NH}_{4} \mathrm{Cl}-\mathrm{P}$ amount was observed in XD4 $(187.15 \mathrm{mg} / \mathrm{kg})$, which was almost two times higher than that in site XD1 $(94.11 \mathrm{mg} / \mathrm{kg})$. The percentage of $\mathrm{NH}_{4} \mathrm{Cl}-\mathrm{P}$ contributing to TP increased from down to upper reaches of Xiangxi Bay in 2010 and was in the range of 4.57\% - 8.47\% (March 2009) and 4.85\% - 13.22\% (March 2010) for all sampling sites (Figure 4(b)).

The BD-P, mainly including P bound to Fe-hydroxides and Mn compounds, represents the redox-sensitive P fraction [22]. In dissolved oxygen (DO) depletion environment, the BD-P was released from anaerobic sediments and acted as an internal P source to the overlying water [23]. In Xiangxi Bay, the mean BD-P amounts in sediments were the lowest among the five $\mathrm{P}$ fractions and exhibited high variability in various sampling sites.

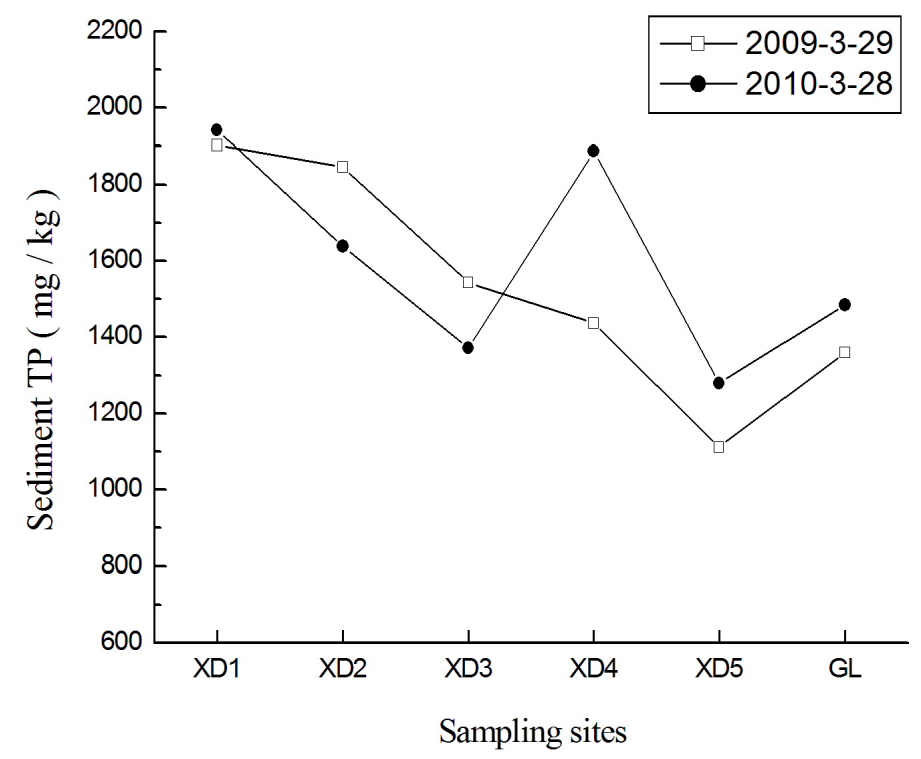

Figure 3. TP contents in sediments of Xiangxi Bay. 

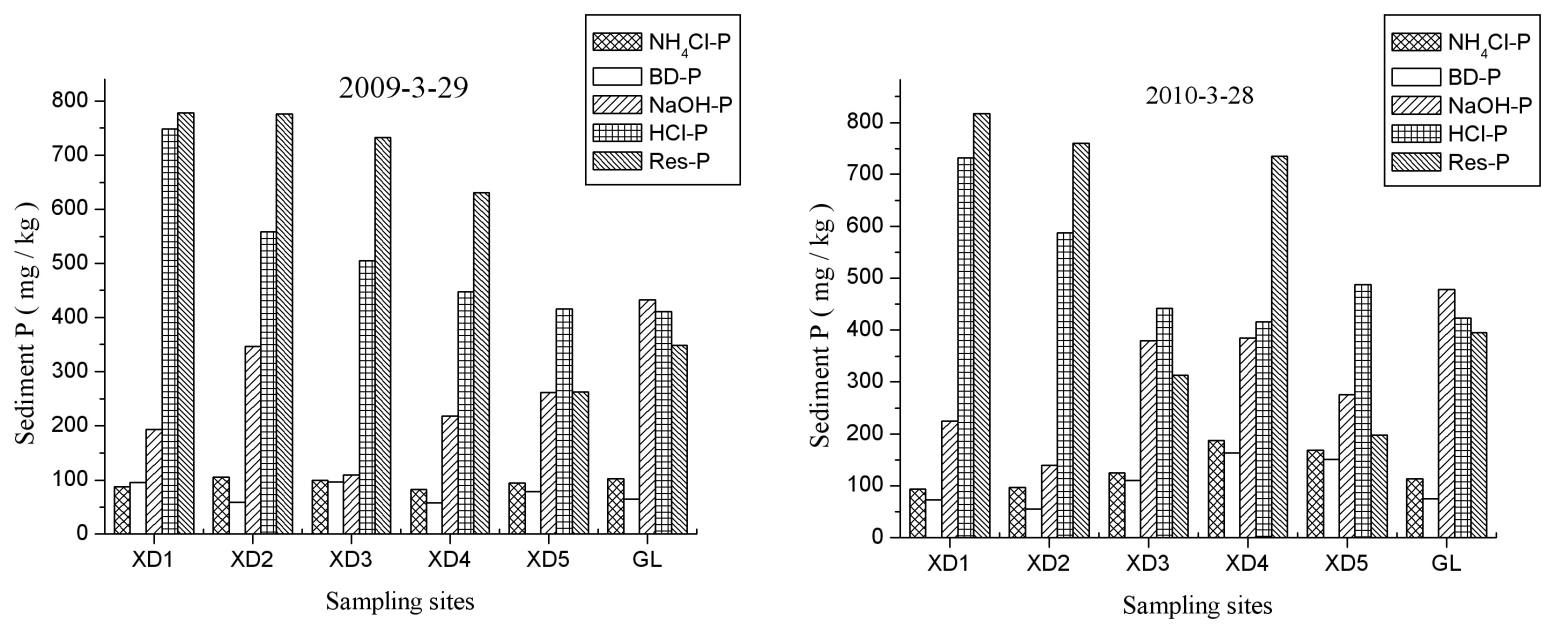

(a)
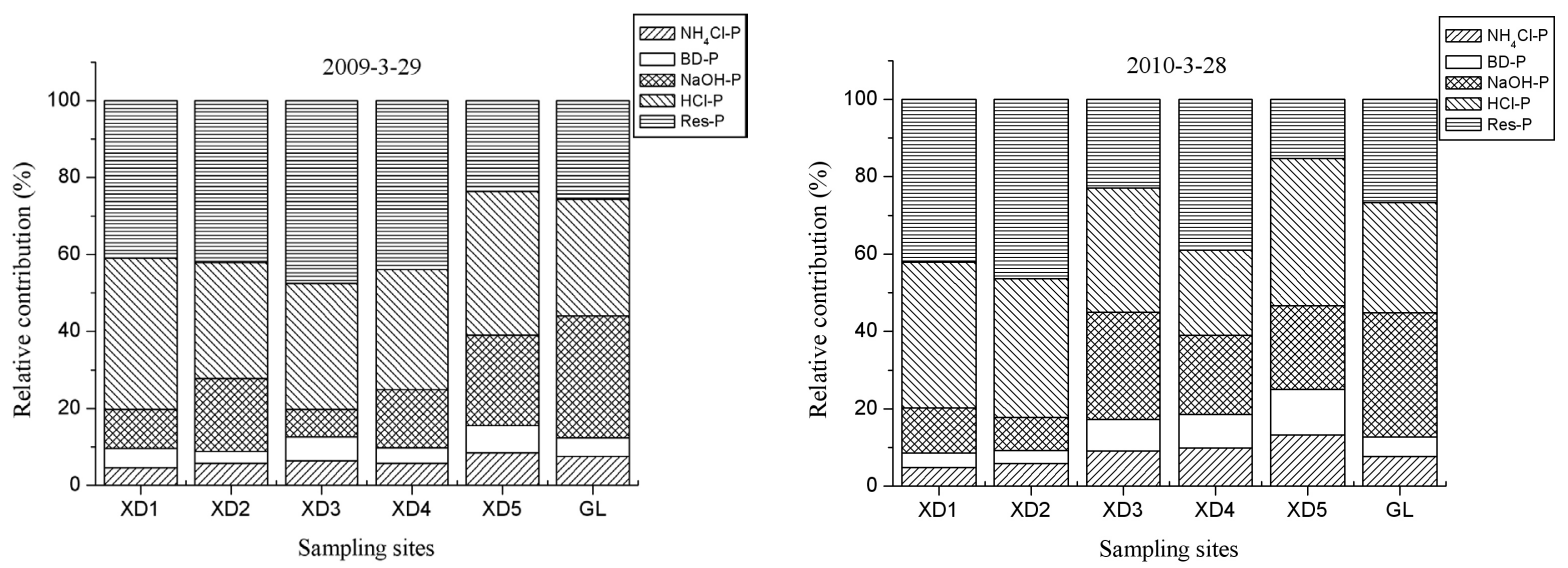

(b)

Figure 4. (a) Contents of different P fractions in sediments of Xiangxi Bay; (b) Relative contribution of different P fractions to TP.

The BD-P amounts in the sediments ranged from $57.80 \mathrm{mg} / \mathrm{kg}$ (XD4) to $96.45 \mathrm{mg} / \mathrm{kg}$ (XD3) in 2009, which contributed $3.15 \%-7.03 \%$ of TP, and from $55.64 \mathrm{mg} / \mathrm{kg}$ (XD2) to $163.34 \mathrm{mg} / \mathrm{kg}$ (XD4) in 2010, which contributed $3.40 \%-11.77 \%$ of TP (Figure 4). DO depletion, high pH level or bacterial activity can enhance contribution of the BD-P fraction [20].

$\mathrm{NaOH}-\mathrm{P}$ is phosphorus bound to metal oxides and can be released for the growth of phytoplankton when anoxic conditions prevail at the sediment-water interface [24]. NaOH-P amounts in the sediments ranged from $139.49 \mathrm{mg} / \mathrm{kg}$ to $477.65 \mathrm{mg} / \mathrm{kg}$, which contributed $7.11 \%$ - 32.17\% of TP. Mean values of NaOH-P contents in sediments were $95.06 \mathrm{mg} / \mathrm{kg}$ (March 2009) and $131.01 \mathrm{mg} / \mathrm{kg}$ (March 2010), respectively. The highest amount was detected in site GL (432.59 mg/kg in 2009 and $477.65 \mathrm{mg} / \mathrm{kg}$ in 2010). NaOH-P was used for the estimation of available $\mathrm{P}$ in the sediments and was indicator of algal available $\mathrm{P}$ [25]. So the risk of phosphorus release in GL was high for algal bloom.

HCl-P was assumed to mainly consist of apatite P, including $\mathrm{P}$ bound to carbonates and traces of hydrolysable organic P. This phosphorus fraction was deemed as a relatively stable fraction in the sediments [26]. HCl-P amounts in the sediments ranged from $410.56 \mathrm{mg} / \mathrm{kg}$ to $748.38 \mathrm{mg} / \mathrm{kg}$, which contributed $22.02 \%-39.33 \%$ to TP with the average of $32.94 \%$ (Figure 4(b)). The high HCl-P content was owing to high portions of calcium mineral $\mathrm{P}$ in Xiangxi Bay.

\subsection{Phosphorus Characteristics of Pore Water and Overlying Water}

Mean values of DTP concentrations in pore water were $0.2236 \mathrm{mg} / \mathrm{L}$ (March 2009) and 0.2854 mg/L (March 
2010), respectively. Those in overlying water were $0.0811 \mathrm{mg} / \mathrm{L}$ (March 2009) and $0.0968 \mathrm{mg} / \mathrm{L}$ (March 2010). DTP concentrations of pore water in all sampling sites in 2010 were higher than those in 2009 except XD2 (Figure 5(a)). The maximum DTP concentration of pore water was $0.3648 \mathrm{mg} / \mathrm{L}$ (site XD4, March 2010). DTP concentrations of overlying water increased from XD2 to XD5, which reached to the maximum values in site XD5 (0.1130 mg/L in 2009 and 0.1550 mg/L in 2010) (Figure 5(b)).

The relationships between DTP of pore water and different P fractions in the sediments are shown in Figure 6. It can be concluded that the DTP concentrations of pore water were strongly in positive correlations with $\mathrm{NH}_{4} \mathrm{Cl}-\mathrm{P}(\mathrm{R}=0.9752, \mathrm{P}<0.01)$ and BD-P $(\mathrm{R}=0.8516, \mathrm{P}<0.01)$. The $\mathrm{DTP}$ concentrations of overlying water were also in positive correlations with $\mathrm{NH}_{4} \mathrm{Cl}-\mathrm{P}(\mathrm{R}=0.7306, \mathrm{P}<0.01)$ and $\mathrm{BD}-\mathrm{P}(\mathrm{R}=0.7150, \mathrm{P}<0.01)$ (Figure 7). This indicates that $\mathrm{NH}_{4} \mathrm{Cl}-\mathrm{P}$ and $\mathrm{BD}-\mathrm{P}$ may be easily released from the sediments in Xiangxi Bay, and they were main fractions of the release phosphorus source in the sediments and of the sources for the overlying water.

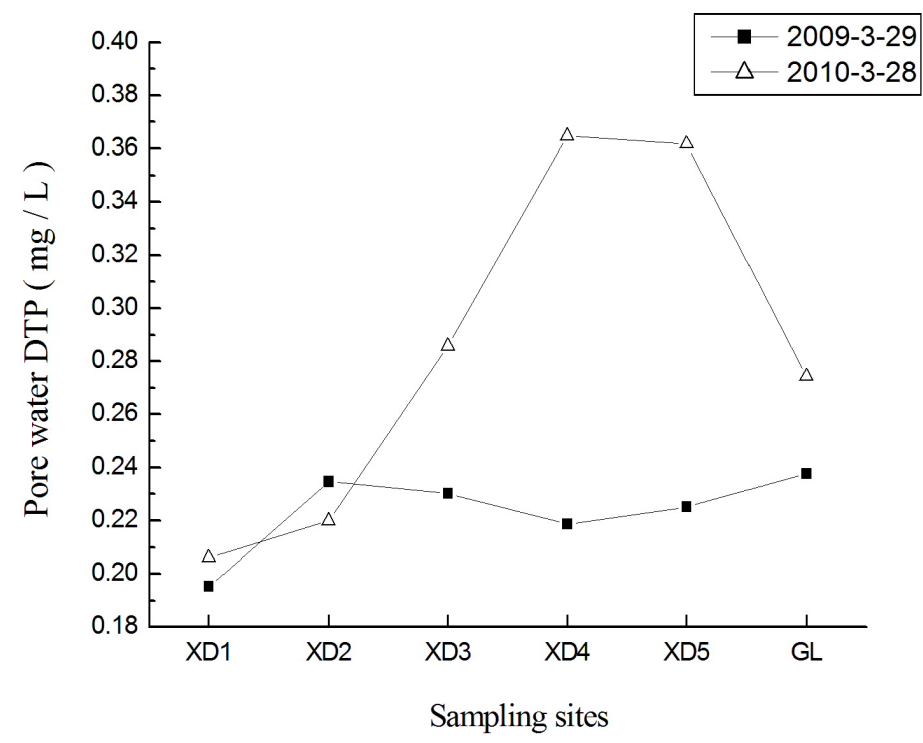

(a)

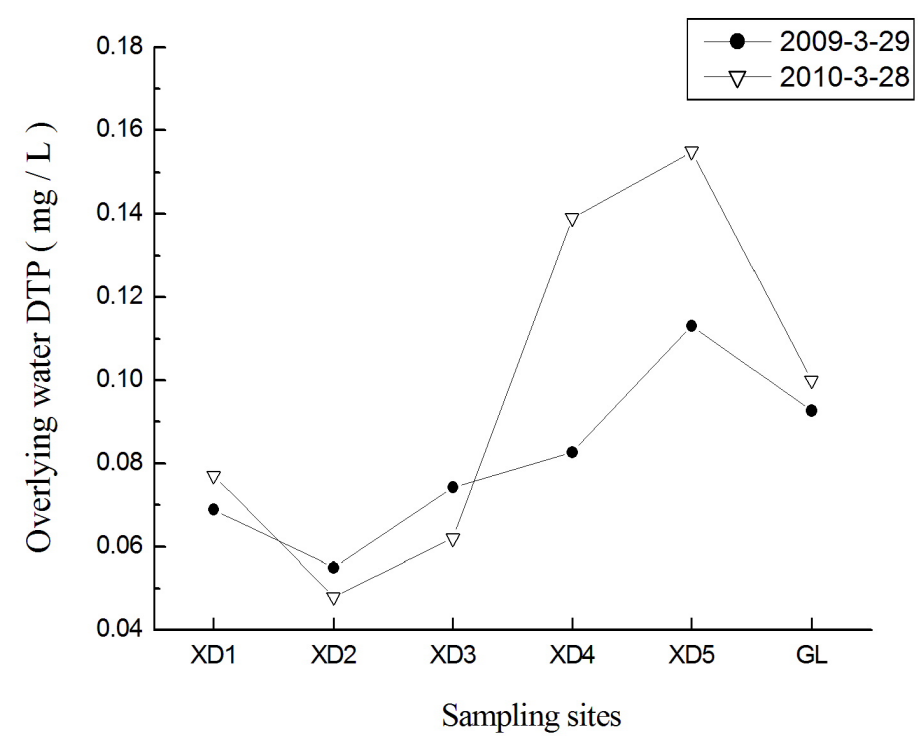

(b)

Figure 5. DTP concentrations of pore water (a) and overlying water (b) in Xiangxi Bay sediments. 

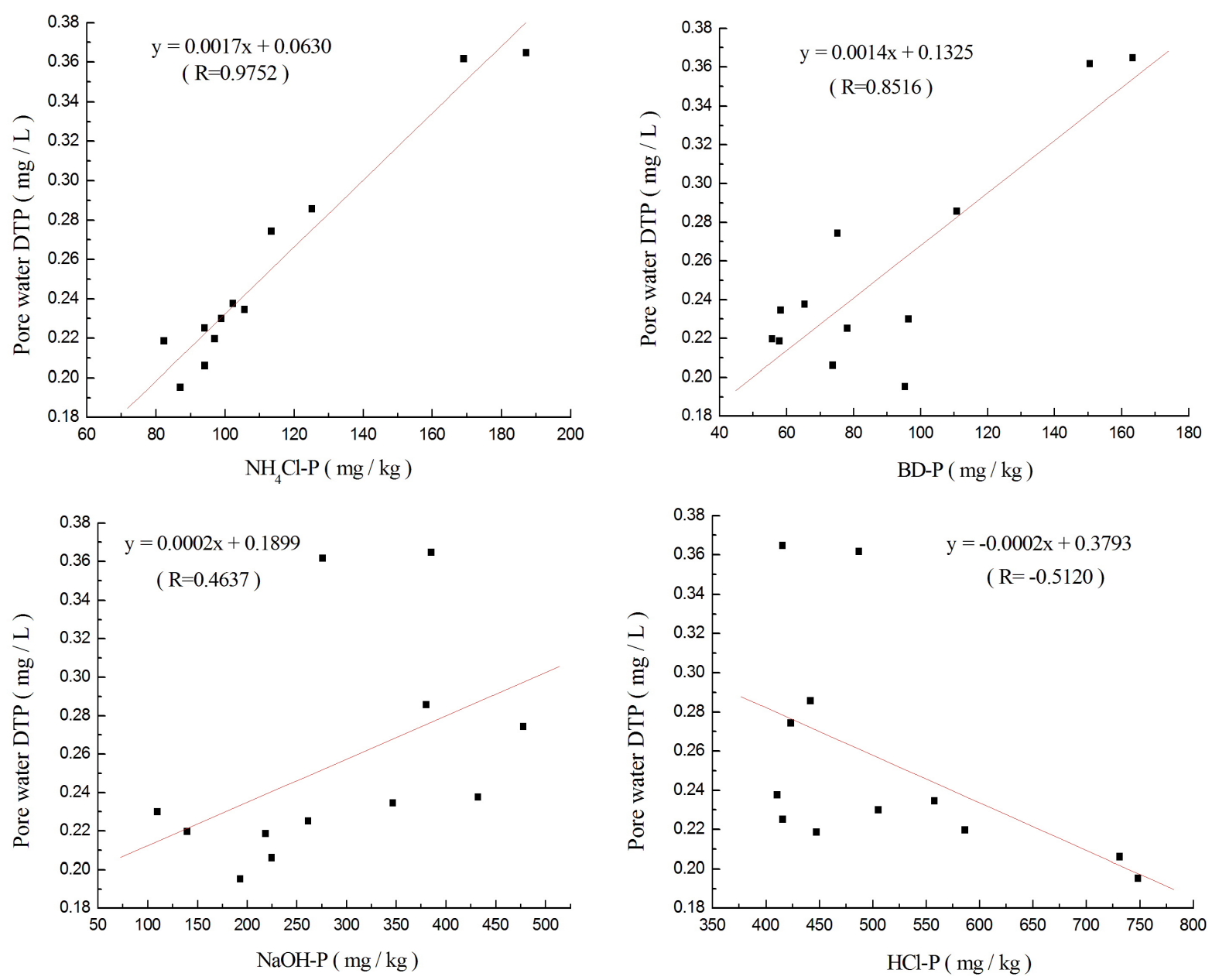

Figure 6. Relationships between DTP of pore water and different P fractions in Xiangxi Bay sediments.
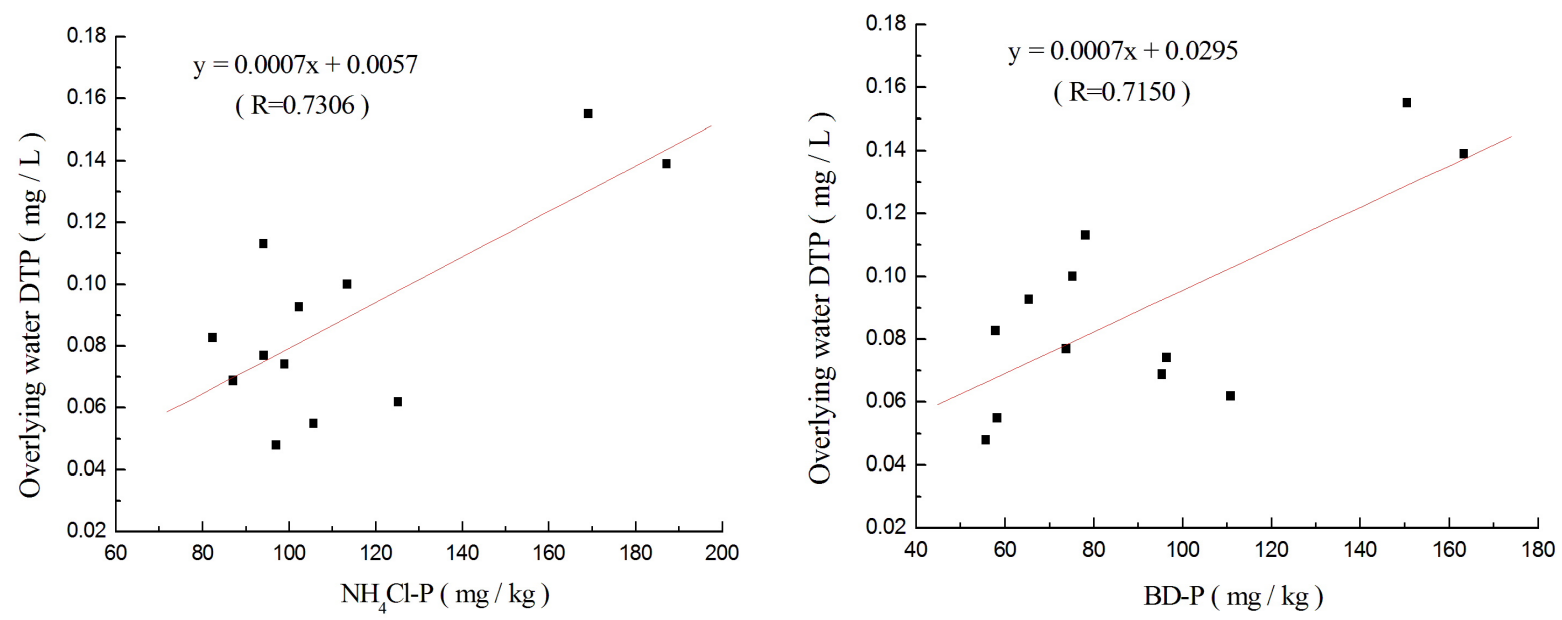

Figure 7. Relationships between DTP of overlying water and different P fractions in Xiangxi Bay sediments.

\section{Conclusion}

Spatial and temporal distribution characteristics of TP and phosphorus fractions in the sediments of Xiangxi Bay were investigated. The contents of TP and different phosphorus fractions in the sediments varied greatly in sam- 
pling sites. TP contents ranged from $1111.29 \mathrm{mg} / \mathrm{kg}$ to $1941.29 \mathrm{mg} / \mathrm{kg}$ with the mean value of $1533.09 \mathrm{mg} / \mathrm{kg}$ in 2009 and $1600.48 \mathrm{mg} / \mathrm{kg}$ in 2010. Phosphorus contents in $\mathrm{NH}_{4} \mathrm{Cl}-\mathrm{P}, \mathrm{BD}-\mathrm{P}, \mathrm{NaOH}-\mathrm{P}$, and HCl-P ranged from 82.33 to $187.15 \mathrm{mg} / \mathrm{kg}, 55.64$ to $163.34 \mathrm{mg} / \mathrm{kg}, 109.63$ to $477.65 \mathrm{mg} / \mathrm{kg}$, and 410.56 to $748.38 \mathrm{mg} / \mathrm{kg}$, respectively. For mean values of all the sediment samples, the rank order of phosphorus fractions was: Res-P > HCl-P > $\mathrm{NaOH}-\mathrm{P}>\mathrm{NH}_{4} \mathrm{Cl}-\mathrm{P}>\mathrm{BD}-\mathrm{P}$, which indicated that the sediments of Xiangxi Bay were mesotrophic. Dissolved total phosphorus of pore water and overlying water all have positive correlations with $\mathrm{NH}_{4} \mathrm{Cl}-\mathrm{P}$ and $\mathrm{BD}-\mathrm{P}$. $\mathrm{NH}_{4} \mathrm{Cl}-\mathrm{P}$ and BD-P may be easily released from the sediments and contributed mostly as the release phosphorus source in the sediments of Xiangxi Bay. The results reported herein would be helpful in developing effective management to control internal phosphorus-loading release in the Xiangxi Bay sediments.

\section{Acknowledgements}

This work was funded by National Natural Science Foundation of China (No. 50679038, 51009080), National Water Special Project of China (2008ZX07104-004) and Science Foundation of China Three Gorges University (No. 1112046). We thank Daobin Ji, Zhengjian Yang, Jun Ma, Song Kong, Niansan Hu, Yu Zhang, Jingfeng Xu, Shuyong Hu and Xia Yang for their assistance in the field and lab.

\section{References}

[1] Lijklema, L., Koelmans, A.A. and Portielje, R. (1993) Water Quality Impacts of Sediment Pollution and the Role of Early Diagenesis. Water Science and Technology, 28, 1-12.

[2] Ramm, K. and Scheps, V. (1997) Phosphorus Balance of a Polytrophic Shallow Lake with the Consideration of Phosphorus Release. Hydrobiologia, 343, 43-53. http://dx.doi.org/10.1023/A:1017092618517

[3] Zhou, Q., Gibson, C.E. and Zhu, Y. (2001) Evaluation of Phosphorus Bioavailability in Sediments of Three Contrasting Lakes in China and the UK. Chemosphere, 42, 221-225. http://dx.doi.org/10.1016/S0045-6535(00)00129-6

[4] Stumm, W. and Morgan, J. J. (1996) Aquatic Chemistry. 3rd Edition, John Wiley \& Sons, New York.

[5] Furumai, H., Kondo, T. and Ohgaki, S. (1989) Phosphorus Exchange Kinetics and Exchangeable Phosphorus Forms in Sediments. Water Research, 23, 685-691. http://dx.doi.org/10.1016/0043-1354(89)90200-5

[6] Stimson, J. and larned, S.T. (2000) Nitrogen Efflux from the Sediments of a Subtropical Bay and the Potential Contribution to Macroalgal Nutrient Requirements. Journal of Experimental Marine Biology and Ecology, 252, 159-180. http://dx.doi.org/10.1016/S0022-0981(00)00230-6

[7] Lu, X.X., Song, J.M., Li, X.G., Yuan, H.M., Zhan, T.R., Li, N. and Gao, X.L. (2005) Geochemical Characteristics of Nitrogen in the Southern Yellow Sea Surface Sediments. Journal of Marine Systems, 56, 17-27. http://dx.doi.org/10.1016/j.jmarsys.2004.06.009

[8] Steinman, A., Chu, X.F. and Ogdahl, M. (2009) Spatial and Temporal Variability of Internal and External Phosphorus Loads in Mona Lake, Michigan. Aquatic Ecology, 43, 1-18. http://dx.doi.org/10.1007/s10452-007-9147-6

[9] Wu, J.G., Huang, J.H., Han, X.G., Xie, Z.Q. and Gao, X.M. (2003) Three-Gorge Dam-Experiment in Habitat Fragmentation? Science, 300, 1239-1240. http://dx.doi.org/10.1126/science.1083312

[10] Ye, L., Li, D.F., Tang, T., Qu, X.D. and Cai, Q.H. (2003) Spatial Distribution of Water Quality in Xiangxi River, China. Chinese Journal of Applied Ecology, 14, 1959-1962.

[11] Tang, T., Li, D.F., Pan, W.B., Qu, X.D. and Cai, Q.H. (2004) River Continuum Characteristics of Xiangxi River. Chinese Journal of Applied Ecology, 15, 141-144.

[12] Wang, H.Y. (2005) Effects of the Three Gorges Reservoir on the Water Environment of the Xiangxi River with the Proposal of Countermeasures. Resources and Environment in the Yangtze Basin, 14, 233-237.

[13] Luo, H.J., Liu, D.F., Ji, D.B., Huang, Y.L. and Huang, Y.P. (2009) Influence Factors Analysis to Chlorophyll $a$ of Spring Algal Bloom in Xiangxi Bay of Three Gorges Reservoir. Journal of Water Resource and Protection, 3, 188-194. http://dx.doi.org/10.4236/jwarp.2009.13023

[14] Yang, Z.J., Liu, D.F., Ji, D.B. and Xiao, S.B. (2010) Influence of the Impounding Process of the Three Gorges Reservoir up to Water Level $172.5 \mathrm{~m}$ on Water Eutrophication in the Xiangxi Bay. Science China Technological Sciences, 53, 1114-1125. http://dx.doi.org/10.1007/s11431-009-0387-7

[15] Dai, H.C., Zheng, T.G. and liu, D.F. (2010) Effects of Reservoir Impounding on Key Ecological Factors in the Three Gorges Region. Procedia Environmental Sciences, 2, 15-24. http://dx.doi.org/10.1016/j.proenv.2010.10.004

[16] Wang, L., Cai, Q.H., Tan, L. and Kong, L.H. (2011) Phytoplankton Development and Ecological Status during a Cyanobacterial Bloom in a Tributary Bay of the Three Gorges Reservoir, China. Science of the Total Environment, 409, 
3820-3828. http://dx.doi.org/10.1016/j.scitotenv.2011.06.041

[17] Murphy, J. and Riley, J.P. (1962) A Modified Single Solution Method for the Determination of Phosphate in Natural Water. Analytica Chimica Acta, 27, 31-36. http://dx.doi.org/10.1016/S0003-2670(00)88444-5

[18] Psenner, R., Boström, B. and Dinka, M. (1988) Fractionation of Phosphorus in Suspended Matter and Sediments. Archiv Hydrobiol Beih Ergeb Limnol, 30, 98-109.

[19] Hupfer, M., Gachter, R. and Giovanoli, R. (1995) Transformation of Phosphorus Species in Settling Seston and during Early Sediment Diagenesis. Aquatic Science, 57, 305-324. http://dx.doi.org/10.1007/BF00878395

[20] Kaiserli, A., Voutsa, D. and Samara, C. (2002) Phosphorus Fractionation in Lake Sediments—Lakes Volvi and Koronia, N. Greece. Chemosphere, 46, 1147-1155. http://dx.doi.org/10.1016/S0045-6535(01)00242-9

[21] Rydin, E. (2000) Potentially Mobile Phosphorus in Lake Erken Sediment. Water Research, 34, 2037-2042. http://dx.doi.org/10.1016/S0043-1354(99)00375-9

[22] Kozerski, H. and Kleeberg, A. (1998) The Sediments and the Benthic Pelagic Exchange in the Shallow Lake Muggelsee. International Review of Hydrobiology, 83, 77-112. http://dx.doi.org/10.1002/iroh.19980830109

[23] Kleeberg, A. and Kozerski, H. (1997) Phosphorus Release in Lake Großer Müggelsee and Its Implications for Lake Restoration. Hydrobiologia, 342-343, 9-26. http://dx.doi.org/10.1023/A:1017079029053

[24] Ting, D.S. and Appan, A. (1996) General Characteristics and Fractions of Phosphorus in Aquatic Sediments of Two Tropical Reservoirs. Water Science and Technology, 34, 53-59. http://dx.doi.org/10.1016/S0273-1223(96)00724-X

[25] Zhou, Q., Gibson, C.E. and Zhu, Y. (2001) Evaluation of Phosphorus Bioavailability in Sediments of Three Contrasting Lakes in China and the UK. Chemosphere, 42, 221-225. http://dx.doi.org/10.1016/S0045-6535(00)00129-6

[26] Gonsiorezyk, T., Casper, P. and Koschel, R. (1998) Phosphorus-Binding Forms in the Sediment of an Oligotrophic and an Eutrophic Hardwater Lake of the Baltic Lake District (Germany). Water Science and Technology, 37, 51-58. http://dx.doi.org/10.1016/S0273-1223(98)00055-9 